\title{
IMPLEMENTASIPAKANSAPIPOTONGBENTUKPELLET BERBASIS LIMBAH PERKEBUNANSAWIT PADAKELOMPOKTANI SUMBER MAKMURKECAMATANARUT SELATANKABUPATEN KOTAWARINGINBARAT
}

\author{
Ida Ketut Mudhita $\left.{ }^{1}\right)^{*}$ dan Saprudin ${ }^{2)}$ \\ ${ }^{1)}$ Program Studi Peternakan Fakultas Pertanian Universitas Antakusuma \\ ${ }^{2)}$ Program Studi Agribisnis Fakultas Pertanian Universitas Antakusuma \\ 1) Email: idakmudita@gmail.com'; saprudinuntama@gmail.com ${ }^{2)}$ \\ Corresponding author:idakmudita@gmail.com
}

\begin{tabular}{|l|l|l|}
\hline Dikirim: 20,01, 2020 & Direvisi: 24,02, 2020 & Diterbitkan: 28,02, 2020 \\
\hline
\end{tabular}

\begin{abstract}
Abstrak
Pengabdian masyarakat ini bertujuan untuk memberikan pelatihan dan pendampingan kepada Kelompok Tani Subur Makmur di Desa Natai Raya Kecamatan Arut Selatan Kabupaten Kotawaringin Barat Provinsi Kalimantan Tengah terkait pemeliharaan sapi Bali dan pengolahan pakan ternak. Metode yang digunakan yaitupolaintegrasisapisawit. Teknik pengolahan pakan ternak menggunakan mikroba dekomposisi serat. Proses pengolahan produksi pakan ternak dengan memanfaatkan potensiperkebunan sawitdengan memfermentasipelepahsawitmenggunakanmikrobadekomposisi serat agar ikatan seratnya menjadi lunak dan mudah tercerna kemudian dicampur dengan hijauan legum penutup tanah dan bungkil sawit dijadikan pakan berbentuk pellet dengan formula yang tepat dan diolah menggunakan mesinpelleting. Produk telah di ujicoba pada induksapi dananaksapimilikanggota mitra pengabdian.Hasil akhir pengabdian mayarakat ini berupa ilmu pengetahuan dan meningkatkankemampuan mitra dalam mempraktekkan teknologi pelleting sehingga mampu memproduksi pakan ternak sapi berbentuk pellet yang efisien dan tahan lama.
\end{abstract}

Kata Kunci: Pola integrasi sapi sawit, fermentasimikroba, pelleting

\section{Abstract}

This community service aims to provide training and assistance to the Subur Makmur Farmer Group in Natai Raya Village, South Arut District, Kotawaringin Barat Regency, Central Kalimantan Province, related to raising Bali cattle and processing animal feed.The method used is the palm oil - cattle integration. Animal feed processing techniques use microbial fiber decomposition. The process of processing animal feed production by utilizing the potential of oil palm plantations by fermenting the palm fronds using microbial decomposition of fibers so that the binding of the fibers becomes soft and easily digested then mixed with forage legumes of ground cover and oil palm cake into pellet-shaped feed with the right formula and processed using a pelleting machine.The products have been on trial in cows and calves belonging to members of partners. The end result of this community service in the form of science and improve the ability of partners in practicing pelleting technology so that they are able to produce pellet-shaped cattle feed that is efficient and durable.

Keywords: Palm oil-cattle integration, microbial fermentation, pelleting 
Kualitas pakan ternak sapi potong sangat penting mempengaruhi kesehatan dan kualitas daging yang dihasilkan. Akan tetapi pada umumnya peternak sapi potong menghadapi permasalahan terkait persediaan pakan ternak yang berkualitas dan tahan lama, serta ketersediaan sumberdaya manusia (peternak) yang memiliki kemampuan dalam memproduksi pakan ternak. Hal tersebut juga menjadi hambatan dan kelemahan yang dialami oleh peternak sapi potong di Kabupaten Kotawaringin Barat. Selama ini peternak mencarikan pakan dari kebun berupa rumput lapangan yang lokasi pengambilan rumput sekitar 3-4 km dari kandang dan akan menghabiskan waktu untuk mengaritsekitr 5 jam. Hal tersebuttentunyasangat berpengaruh terhadap perkembangan sapi yang diperlihara karena rumput lapangan belum mencukupi kebutuhan nutrein sapi potong apalagi sapi tersebut bunting.

Maka, untuk mengatasi permasalahan tersebut team pengabdian masyarakat LPPM Universitas Antakusumayang didanai Kemenristekdikti 2019 menawarkan pelatihan dan pendampingan PKM kepada mitra yaitu "Kelompok tani Sumber Makmur" dalam upaya mengimplementasi pakan sapi potong bentuk pellet berbasis limbah perkebunan sawit.

Ada beberapa pertimbangan PKM bermitra dengan kelompok tani Sumber Makmur antara laian: Kelompok ini telah didirikan pada tahun 2007 oleh masyarakat transmigrasi Desa Natai Raya Kecamatan Arut Selatan Kota waringin Barat dengan mata pencaharian beternak sapi potong dan berkebun sawit. Jumlah awal sapi Bali betina tahun 2012 sebanyak 40 ekor bantuan dari Dinas Pertanian dan Peternakan Kabupaten Kota waringin Barat, saat ini menjadi 101 ekor dengan masing-masing tingkat kepemilikan sekitar 2-6 ekor/anggota. Kelompok ini belum mempunyai SDM yang cukup untuk menangani reproduksi sapi potong, hanya ada seoarang petugas Inseminasi Buatan/Inseminator (IB) dari Dinas Peternakan Kabupaten Kotawaringin Barat, sedangkan petugas kesehatan hewan akan datang bila diperlukan.

Selain itu keuggulan yang dimiliki mitra yaitu bahan baku untuk membuat pakan ternak telah tersedia di lokasi pemeliharaan sapi. Lokasi yang dikelilingi kebun kelapa sawit, baik milik anggota kelompok atau milik perusahaan. Dalam menjalankan usaha agribisnis ternak potong, kelompok tersebut belum mendapatkan pendampingan dari Sarjana Membangun Desa (SMD) program pemerintah pusat yang dapat membantu dalam mengelola usaha tersebut, sehingga teknologi dalam manajemen ternak potong belum optimal walaupun beberapa anggotasudah mendapatkan pelatihan reproduksi.

Dalam implementasi pola integrasi sawit dan sapi memiliki peluang basar karena belum dilakukannya pengolahan pakan dari perkebunan sawit seperti pengolahan pelepah sawit. Padahal sudah ada mesin pencacah pelepah bantuan Dinas Perkebunan tetapi tidak dipergunakan lagi karena hasil cacahan masih keras dan kasar, masih ada lidi yang panjangpanjang sehingga apabila diberikan pada sapi akan membahayakan pencernaan.

Dengan adanya pengolahan pelepah sawit, seperti fermentasi pelepah dengan enzim dan pembuatan pakan dari campuran hijauan dari tanaman antar pohon sawit, pelepah terfermentasi dan bungkil sawit berbentuk pellet maka diharapkan ketersediaan pakan berkualitas akan cukup.

METODE

Kegiatan pengabdian berlangsug mulai bulan Mei - Oktober 2019. Mitra pengabdian adalah Kelompok Tani Sumber Makmur.Lokasi pengabdian berada di Desa Natai Raya Kecamatan Arut Selatan Kabupaten Kotawaringin Barat. Peserta pelakasanaan pengabdian sejumlah 20 anggota kelompok tani dan 4 Mahasiswa prodi Peternakan Fakultas Pertanian Universitas Antakusuma. Metode yang digunakan dalam kegiatan pelatihan adalah metode pelatihan partisipatif yang melibatkan peserta pelatihan yang merupakan anggota mitra dalam setiap tahapan pelatihan mulai dari pra pelatihan hingga tahapan evaluasi pelatihan 
(Participant Learning Center/PLC). Terkait dengan pelatihan produksi pakan ternak integrasi sawit sapi berupa Pellet dihadirkan para ahli terkait bidangnya sebagai pelatih/instruktur/ahli pengolahan dengan teknologi Pelleting.Secara rinci metode pelaksanaan masing-masing kegiatan disajikan pada bagan alur sebagai berikut:

Tabel 1. Kegiatan, Tujuan, Metode serta bahan dan Alat

\begin{tabular}{|c|c|c|c|c|}
\hline No & Kegiatan & Tujuan Kegiatan & Metode & Bahan dan Alat \\
\hline 1 & $\begin{array}{l}\text { Kontrak } \\
\text { Belajar }\end{array}$ & $\begin{array}{l}\text { Membangun kesepahaman } \\
\text { mengenai tujuan dan } \\
\text { pelaksanaan PPMPI antara } \\
\text { Tim dan Mitra }\end{array}$ & $\begin{array}{l}\text { Ceramah, } \\
\text { diskusi }\end{array}$ & $\begin{array}{l}\text { White board, spidol, } \\
\text { Kertas Plano }\end{array}$ \\
\hline 2 & $\begin{array}{l}\text { Pemaparan } \\
\text { materi } \\
\text { terkait bahan } \\
\text { baku, proses } \\
\text { pengolahan, } \\
\text { dan produksi }\end{array}$ & $\begin{array}{l}\text { Anggota pelatihan diberikan } \\
\text { pemahaman } \\
\text { komposisi bahan baku, } \\
\text { tahap-tahap Fentang } \\
\text { Pelepah Sawit, Pembuatan } \\
\text { Pakan Pellet, peralatan } \\
\text { /teknologi/ dan aplikasi } \\
\text { pada sapi. }\end{array}$ & $\begin{array}{l}\text { Ceramah, } \\
\text { Demonstrasi }\end{array}$ & $\begin{array}{l}\text { Daftar Hadir } \\
\text { Materi-materi } \\
\text { integrasi pengolahan } \\
\text { limbah sawit - pakan } \\
\text { ternak sapi potong. }\end{array}$ \\
\hline 3 & $\begin{array}{l}\text { Pelatihan } \\
\text { pengolahan } \\
\text { atau } \\
\text { komposisi } \\
\text { /proses } \\
\text { Produksi } \\
\text { Olahan } \\
\text { Limbah } \\
\text { Sawit }\end{array}$ & $\begin{array}{l}\text { Melatih anggota kelompok } \\
\text { tani sumber makmur untuk } \\
\text { memproduksi Pellat yang } \\
\text { berkualitas dan tahan lama } \\
\text { dengan komposisi bahan } \\
\text { baku yang tepat. }\end{array}$ & $\begin{array}{l}\text { Praktek } \\
\text { membuat Pellet }\end{array}$ & $\begin{array}{ll}\text { - } & \text { Pelepahsawityang } \\
\text { sudahdifermentasi } \\
\text { - } & \text { hijauandiantarapoh } \\
& \text { on sawit/tanaman } \\
\text { - } & \text { legumepenutuptana } \\
& \text { h. } \\
\text { - } & \text { bungkilintisawit } \\
\text { - } & \text { Tepung tapioka } \\
\text { - } & \text { tetestebu } \\
\text { - } & \text { garam } \\
\text { - } & \text { kapur } \\
\end{array}$ \\
\hline 3 & $\begin{array}{l}\text { Pendamping } \\
\text { an untuk } \\
\text { produksi } \\
\text { Pellet dan } \\
\text { aplikasi } \\
\text { pada sapi } \\
\text { Induk }\end{array}$ & $\begin{array}{l}\text { Menggunakan teknologi } \\
\text { pelleting dan menghasilkan } \\
\text { produk Pellet kelompok tani } \\
\text { sumber makmur. }\end{array}$ & $\begin{array}{l}\text { Pendampingan } \\
\text { dan } \\
\text { memfasilitasi } \\
\text { mitra dalam } \\
\text { produksi produk } \\
\text { pellet untuk siap } \\
\text { dipasarkan } \\
\end{array}$ & $\begin{array}{l}\text { Produk Pellet pakan } \\
\text { ternak sapi } \\
\text { Melakukan aplikasi } \\
\text { pellet pada sapi induk. }\end{array}$ \\
\hline 4 & $\begin{array}{l}\text { Diseminasi } \\
\text { Ke media } \\
\text { cetak dan } \\
\text { Jurnal. }\end{array}$ & $\begin{array}{lr}\text { Menyebarluaskan } & \text { kegiatan } \\
\text { pengabdian } & \text { kepada } \\
\text { masyarakat } & \text { sekaligus } \\
\text { mempromosikan } & \text { produk } \\
\text { kelompok tani } & \text { sumber } \\
\text { makmur ke media masa }\end{array}$ & $\begin{array}{l}1 \text { artikel jurnal } \\
1 \text { publikasi } \\
\text { kegiatan di } \\
\text { koran lokal }\end{array}$ & $\begin{array}{l}\text { Artikel } \\
\text { Dokumentasi kegiatan }\end{array}$ \\
\hline
\end{tabular}

\section{HASIL DAN PEMBAHASAN}

Sebagaimana target capaian yang akan dihasilkan dari aktivitas pengabdian ini adalah meningkatkan pengetahuan dan kemampuan masyarakat atau mitra mitra dalam hal pengolahan produk pakan ternak sapi potong berupa Pellet. Selain itu nilai tambah pakan 
ternak pellet tersebut mengimplmentasikan pola integrasi sawit-sapi dalam pemberdayaan SDM anggota kelompok tani sumber makmur.

Secara khusus target luaran dari kegiatan ini adalah bagi anggota kelompok tani Sumber Makmur di Desa Natai Raya Kecamatan Arut Selatan Kabupaten Kotawaringin Barat berupa : 1) pelatihan pengolahan limbah sawit menjadi produk Pellet sebagai pakan ternak yang berkualitas dan tahan lama 2) Ide produksi pellet pemanfaat teknologi Pelleting yang sudah ada 3) Pemasaran produk Pellet bagi anggota dan peternak sapi umumnya.

Bagi Target yang telah ditetapkan tersebut maka sampai saat ini hasil yang telah dicapai berdasarkan tahapan kegiatannya adalah:

\section{Sosialisasi}

Tahap pertamapelaksanaan pengabdian adalah dengan melakukan sosialisai padaanggotaKelompokTaniSumber MakmurDesaNataiRayaKecamatan Arut Selatan KabupatenKotawaringunBarat,yang diikutioleh20orang peserta.Gambar 1 dibawah iniadalah saatpelaksanaan sosialisasi.
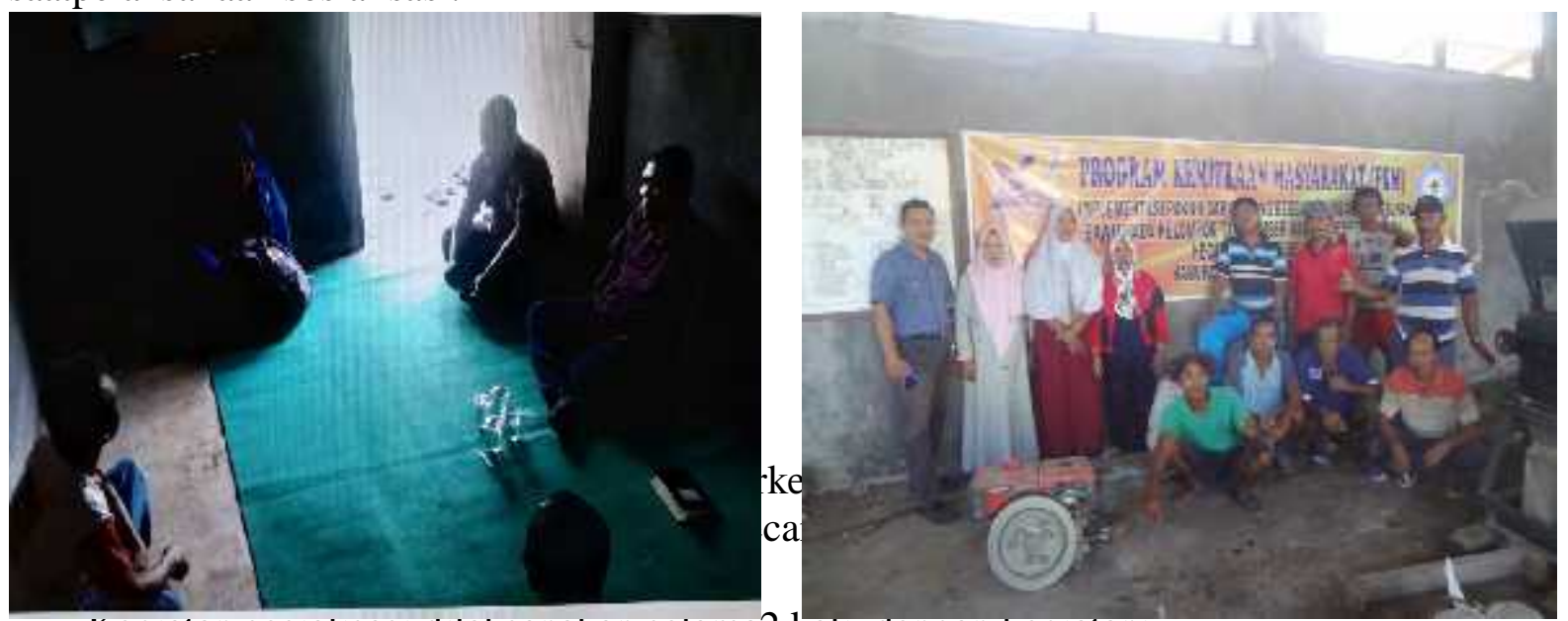

Kegiatan sosıalısası dılaksanakan selama2 kal1, dengan kegıatan:

1. Pemberianteorimanajemen pemeliharaansapi breeding yangbaik

2. Jenispakan yangada diperkebunan sawit

3. Pembuatan pakan dari perkebunan sawit

4. Pembuatan pakan pellet

Peralatan.Pembuatanpakanpelletmenggunakanmesinpelletbuatanlokal

dariSurabayadengankapasitas $50 \mathrm{~kg} / \mathrm{jam}$,diameterkeluaranpellet $2 \mathrm{x} \quad 1,5 \mathrm{~cm}$, penyaring bungkilintisawitmenggunakanayakandenganukuranlubang $0,1 \mathrm{~cm}$ dengan maksud agar sisacangkang yang adadalambungkil tidak ikutdalamproses pelleting.

Teknik Pengolahan yaitu: (1)Bungkilsawitdiayak terlebih dahulu agar sisa cangkang tidak mikut dalamprosespelleting,legumepenutup tanahdihaluskan terlebihdahuludengan caradicacahdenganmesinpencacahhijauandanditepung denganmesinpenepung, pelepahyang sudahdifermentasijugadihaluskandengancaraditepung. (3) campuran ketigabahan pakan sesuai formula dicampur tetes tebu, garam, kapur dan perekat tepung tapiokadimasukkan kedalam mixeragartercampurhomogen, (4) kemudian dimasukkan kedalam mesin pelleting ditambahkan air sedikit demi sedikit agar kadar air sekitar $60 \%$. (5) setelah pakan pelletjadikemudian dijemur agar keringdan disimpan dalamkarung.

\section{Fermentasi pelepah sawit}

Pelepahsawityang dipergunakanuntukprosespembuatanpakanasal perkebunan sawit mempunyaikelemahanyaitu mengandung seratkasar (SK)yang tinggi dan masih adanya lidi yang dapat menggangu lambung sapi. Untuk itu diperlukanperlakuanfisikdanbiologisuntukmenurunkanSK danmelunakkanlidi. Perlakuan 
fisik dengan mencoper pelepahsawit agar menjadi lebih kecilagar gampangdicernasapi,sedangkanperlakuanbiologis dengan menambahkanmikrobayang mengandung enzymeselulaseagarikatan6betaseluloseyang membuatSK tinggi dipisahkan. Gambar 2. memperlihatkan prosesfermentasiselama21 hari.

Hasil chopper pelepah masih menyisakan lidisehinggaperlu diayak sedikitdan nantinyadenganpemberianmikroba3\%yang mengandung enzimselulasedapat memperlunaklidi sehingga lebih mudah dicerna lambung sapi. Para anggota kelompoktempatpengabdianakhirnya pahamapabilaakanmenggunakanpelepah sawitsebagaipakan sapipotongperlu perlakuan dichopper dan diberikan mikroba.

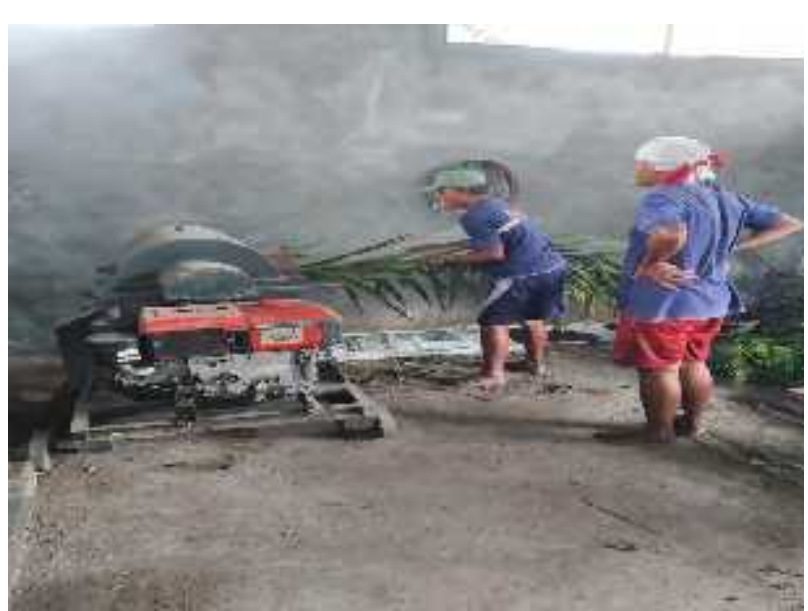

2a. Chooper pelepah

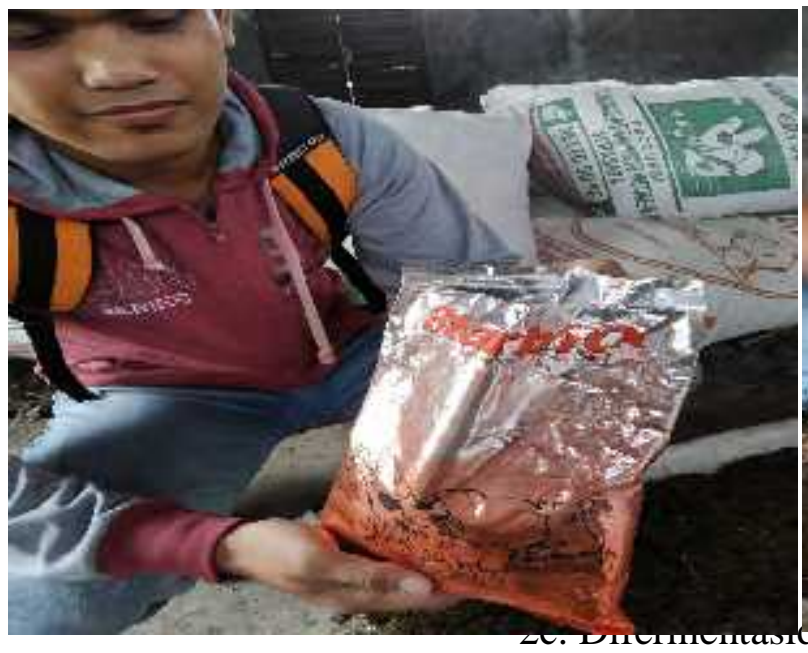

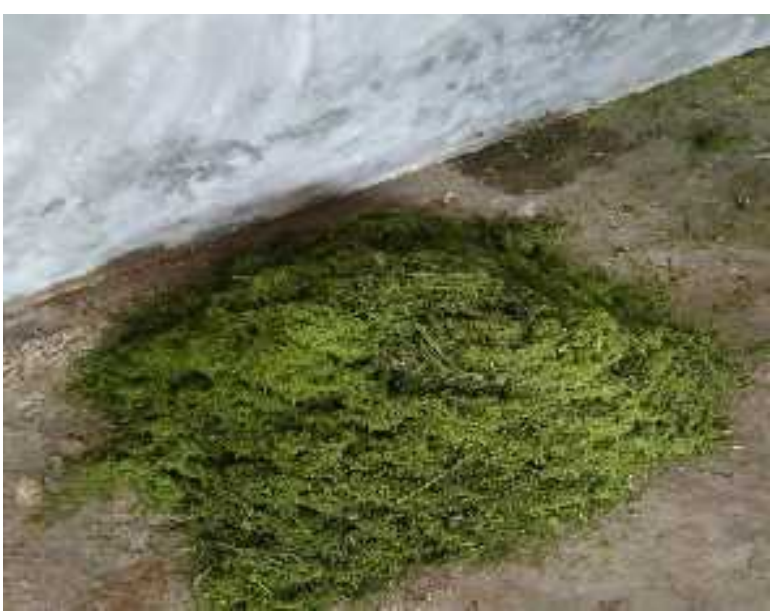

2b. Hasil chooper pelepah

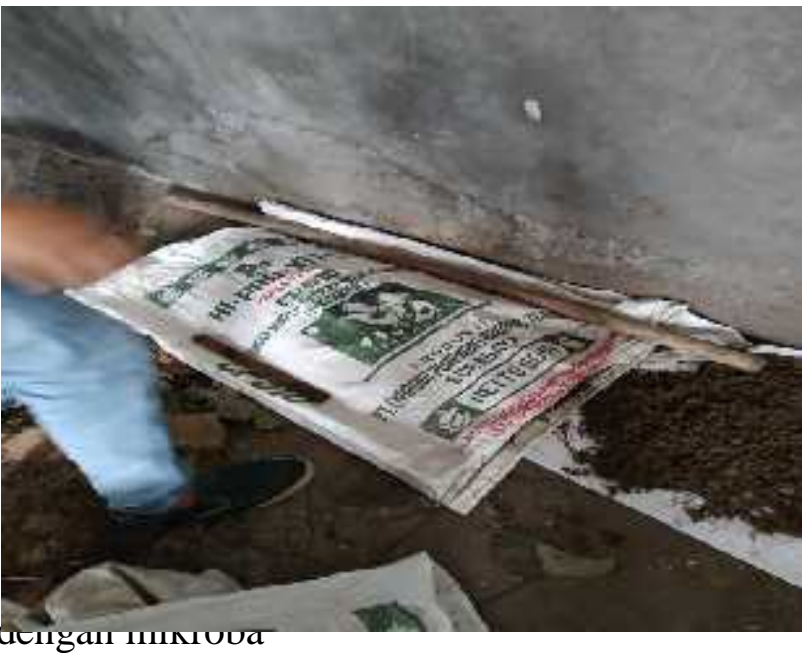

Gambar 2. Fermentasipelepah sawit

Teknik dan bahan baku proses produksi Pellet dengan Fermentasi Pelepah Sawit (gambar 2a,2b, dan 2c) membutuh bahan: (1) Pelepah sawit $1.000 \mathrm{~kg}$ difermentasi agar kandungan serat menjadi lebih rendah. (2) Dosis mikroba enzim yang dipergunakan $6 \%$ dari berat pelepah sawit, sesuai aturan dosis yang dianjurkan. (3) Pelepah sawit dicacah dengan chopper yang sudah dimodifikasi sehingga hasil pelepah menjadi lebih halus, lidi sudah hancur. (4) waktu yang dibutuhkan untuk fermentasi sekitar 6 hari (5) pelepah yang sudah dicampur dengan mikroba ditutup rapat dengan terpal, kemudian dikering anginkan siap untuk sebagai pakan sapi potong. 


\section{Pembuatan Pellet Pakan Sapi Potong}

Pembuatan pakan pellet dengan mempersiapkan bahan baku pakan yang semuanya berasal dari perkebunan sawit seperti: pelepah sawit yang sudah difermentasi, legume penutup tanah Mucuna (Mucunabracteata), dan bungkilinti sawit. Legum penutup tanah yang sengaja ditanam di antara pohon sawit umumnya adalah Calopo produksi 10 ton bahan kering (BK)/ha, protein kasar (PK) 16\%, Total digestible nutrients (TDN) 54,3\%, Puero produksi 10-20 ton BK/ha, PK 16-22\%, TDN 68,7\%, Mucuna produksi 28 ton BK/ha, PK 23\% (Legel, 1990; Sebayang et al., 2004, Mudhita et.al., 2016). Protein daun legum termasuk protein mudah larut atau mudah didegradasi di dalam rumen.

Bahan yang diikutkan dalam pembuatan pellet adalah tetestebu untuk penambah karbohidrat dan dapat meningatkan palatabilitas, garam sebagai penambah mineral, kapur penambah mineral kalsium, dan tepung tapioka untuk perekat.

Jumlah bahan pakan yang diformulasikan untuk pengabdian ini disesuaikan dengan hasil penelitian oleh Mudhita (2017), dengan perincian bahan disajikan pada Tabel 2.

Tabel 2. Komposisi bahan pakan dari perkebunan sawit yang dijadikan pellet

\begin{tabular}{llcl}
\hline No. & \multicolumn{1}{c}{ Bahan pakan } & Persentase & \multicolumn{1}{c}{ Keterangan } \\
\hline 1. & Pelepah sawit & 21 & Sumber serat, karbohidrat \\
2. & Legum Mucuna bracteata & 35 & Sumber protein \\
3. & Bungkil intisawit & 40 & Sumber energy dan protein \\
4. & Garam & 1 & Sumber mineral Na, Mg \\
5. & Kapur & 1 & Sumber mineralcalcium \\
6. & Tetestebu & 1 & Sumber energy dan palatabilitas \\
7. & Tepung tapioka & 1 & Perekat pellet \\
\hline
\end{tabular}

Sumber: Mudhita (2017)

Langkah pertama yang dilakukan adalah melakukan fermentasi pelepah sawit, setelah pencincangan atau chopper pelepah ditambahkan mikroba yang mengandung enzyme selulase (Starbio Ruminansia, New Starbio, Stardec) sebanyak 0,6\%(LHM, 2012). Campuran pelepah dan mikroba diaduk dan disimpan dalam keaadaan an aeroob (didalam terpal) selama21 hari. Teknologi inibertujuan untuk meningkatkan nilai nutrien pelepah sawit dengan menggunakan enzim selula semurni yang mampu melonggarkan ikatan glikosidikbeta-1,4 didalam selulosa, sedodekstrin, selobiosa, dan turunan selulosa lainnya pada pelepah sawit dan bungkil intisawit. Pengolahan pelepah sawit diperlukan karena mempunyai nilai protein kasar rendah sekitar 2-4\% dengan kandungan serat kasar 43\%, dinding sel (NDF) 74,5\%, isisel (ADF) 51,4\% (Lab HMTUGM, 2015). Perlakuan enzim akan meningkatkan kandungan isisel (ADF) sehingga konsumsi dan kecernaan meningkat.

Probiotik Starbio merupakan kumpulan bibit mikroorganisme yang diambil dari lambung sapi yang kemudian diproses dengan pencampuran tanah, akar rumput dan daundaunan atau ranting-ranting daunan-daunan yang dibusukkan. Di dalam pencampuran tersebut mengandung mikroba khusus yang mempunyai fungsi yang berbeda beda, contohnya Cellulomonas Clostridium thermocellulosa sebagai pecerna lemak, Agaricus dan coprinus (pencerna lignin), serta Klebssiella dan Azozpirillumtrasiliensis sebagai pencerna protein (LHM, 2016)

Langkah selanjutnya adalah mengayak pelepah sawit dengan mesin crasher atau ayakan manual. Bungkil sawit juga diayak karena masih mengandung cangkang sawit yang keras dikhawatirkan merusak lambung sapi. Pembuatan pellet disajikan seperti pada Gambar 3 .

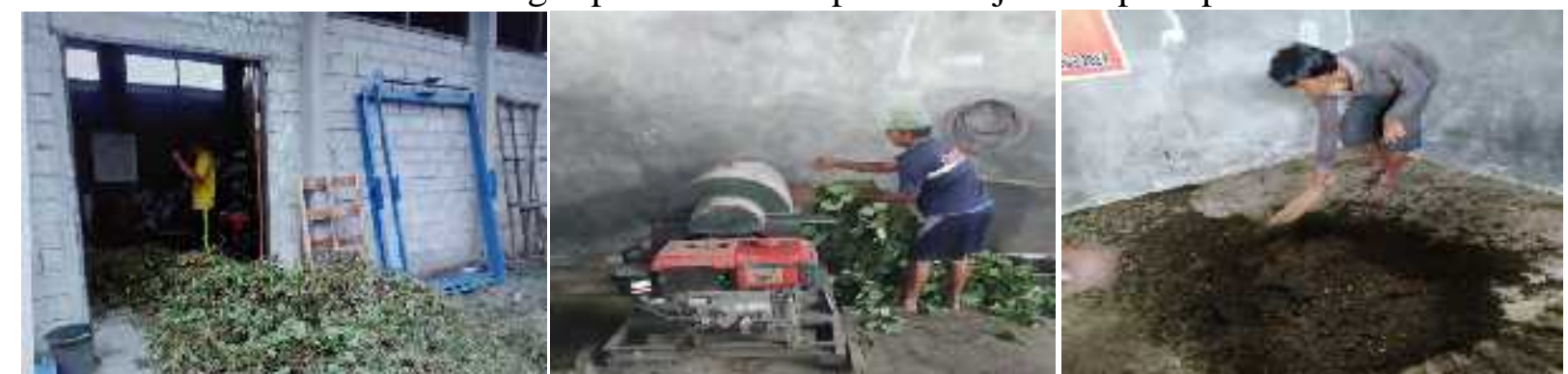




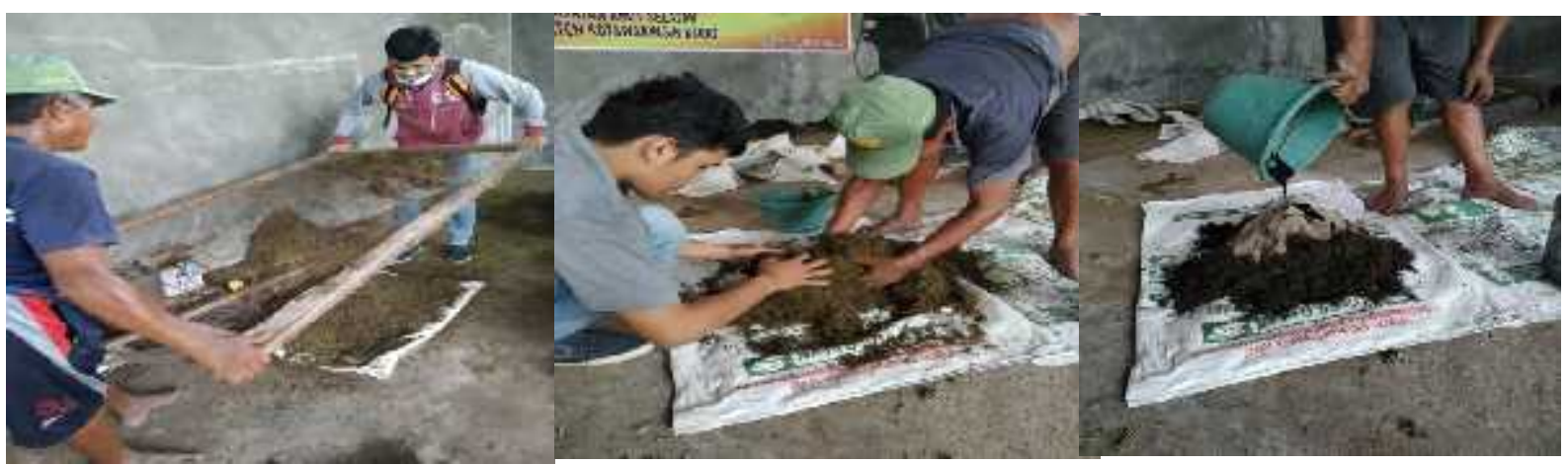

3b. Pencampuran bahan

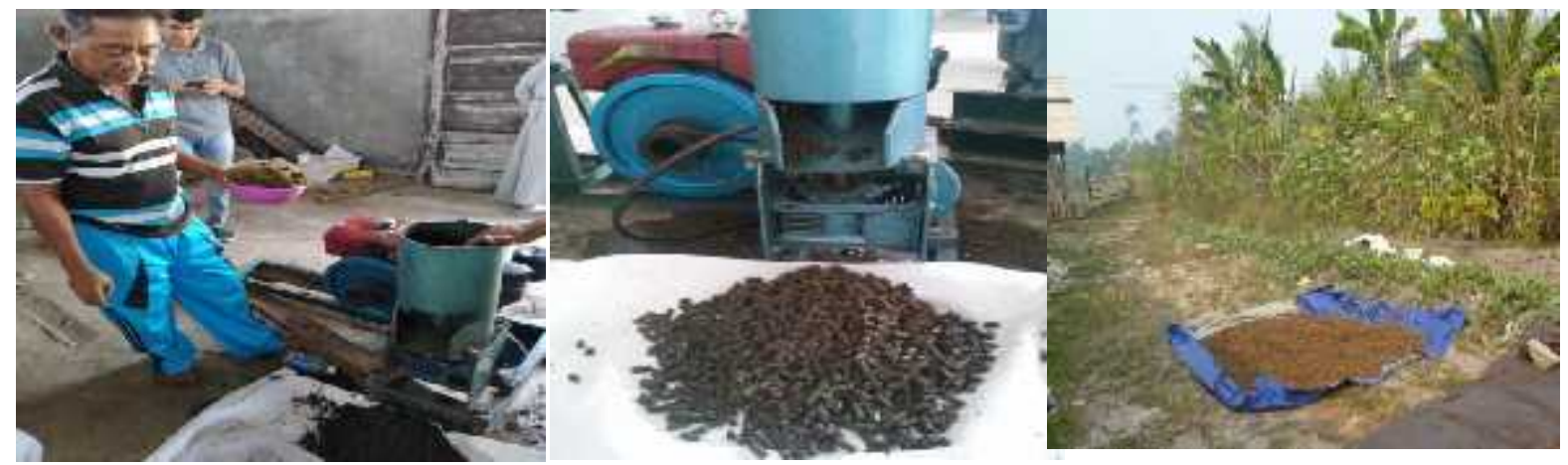

3c. Pembuatan pellet

Gambar 3. Prosespelletingpakan sapiasalperkebunan sawit

Proses pembuatan Pakan Pellet terilustrasi pada gambar 3a, 3b, dan 3c. Untuk membuat pakan pellet menggunakan bahan baku dengan komposisi sebagai berikut:

Bahan: (1) Pelepah sawit yang sudah difermentasi 30\%, (2) hijauan diantara pohon sawit/tanaman legu mepenutup tanah 30\% dan (3) bungkil inti sawit40\%, (4) ditambah perekat dari tepung tapioka2\%, (5) tetes tebu 1\%, (6) garam 0,2\%dan (7) kapur 0,1\%. Air secukupnya.

\section{Nilai nutrien pakan pellet}

Nilai nutrien pakan pellet terlihat pada Tabel 3.

Tabel 3. Nilai nutrien pakan pellet

Parameter

Nilai 
Bahan Kering

Protein Kasar

Lemak Kasar

Serat Kasar

$\mathrm{Abu}$

ETN

Sumber: Laboratorium Teknologi Pakan, Fakultas Peternakan UGM (2019)

Selanjutnya pakan ternak di aplikasikan pada sapi induk untuk menguji kualitas dan ketahan pellet sehingga produk bisa di produksi untuk memenuhi permintaan pasar. Untuk proses ini disajikan pada gambar 4 dibawah ini.
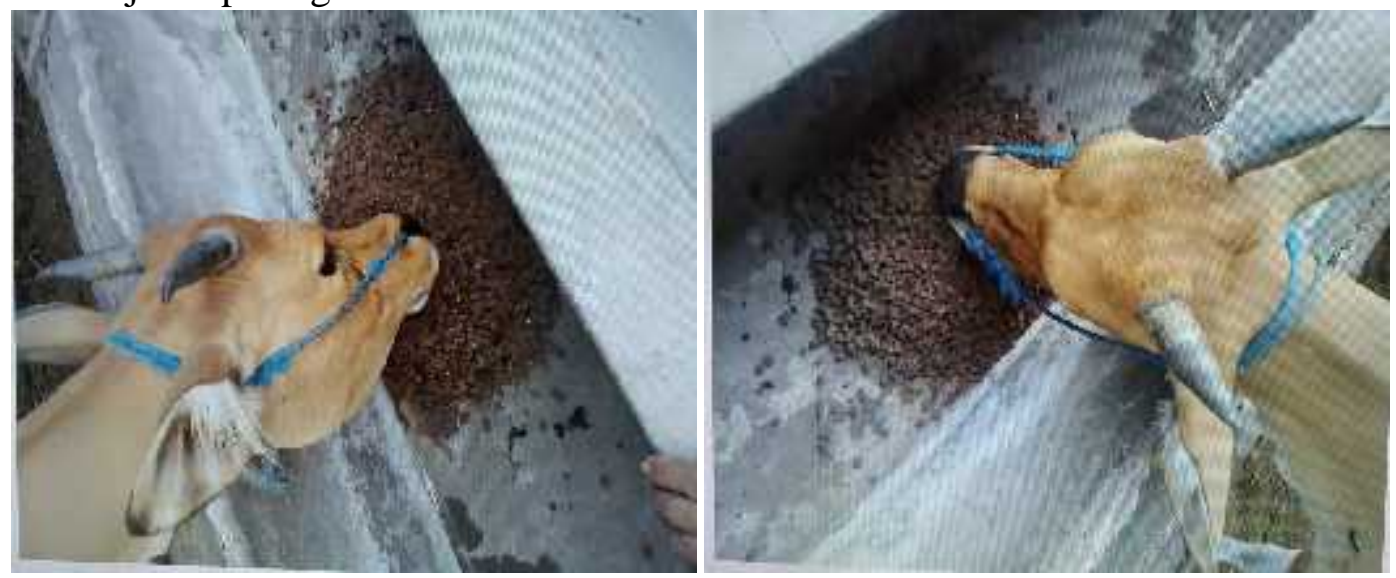

4. Pakan pellet dikonsumsi sapi Induk

\section{Aplikasi Pada Sapi Induk}

Sepuluh ekor sapi induk bunting dipakai untuk uji coba pakan pellet, diberikan sebanyak 3\% dari berat badan sapi. Pakan diberikan selama 2 bulan. Pakan pellet diberikan 2 kalisehari, pagi jam 07.00, dan sore jam 17.00. Pemberian air secara ad libitum. Sapi dimandikan setiap hari secara rutin sekaligus pembersihan kandang. Kontrol kesehatan dilaksanakan dengan memeriksa kondisi sapi secara rutin. Setiap pemberian pakan, sisa pakan masing-masing temak dikumpulkan, kemudian ditimbang untuk menghitung konsumsi pakan.

\section{SIMPULAN}

Kegiatan pengabdian telah dilaksanakan di Desa Natai Raya Kecamatan Arut Selatan Kabupaten Kotawaringin Barat lokasi tempat dimana mitra berada. Beberapa hal yang dapat disimpulkan dari hasil kegiatan Pengabdian Kepada Masyarakat (PKM) pembuatan pakan pellet di Kelompok Sumber Makmur, yaitu:

1. Anggota kelompok Tani Sumber Makmur sangat antusias mengikuti pelatihan, dilihat dengan tekunnya mereka melakukan kegiatan, karena keinginan yang sangat besar untuk membuat pakan pellet.

2.Mitra pengabdian sepakat membentuk kelompok-kelompok usaha yang akan bertanggung jawab memproduksi Pellet pakan ternak sapi yang terintegrasi dengan pemanfaatan limbah sawit. 
3. Terciptanya nilai tambah limbah kebun kelapa sawit dari pelepah sawit yang merupakan hasil penebangan (proning) setelah panen buah tandan segar, bungkil sawit dari limbah pabrik kernel, dan legum mukuna yang diambil dari lahan kebun sawit sebagai bahan baku berkualitas untuk produk pellet sebagai pakan sapi potong.

3. Produk Pellet yang di produksi oleh team pengabdian teruji memiliki kualitas baik dan tahan lama.

4. Meningkatkan SDM sebagai anggota kelompok tani dengan memiliki pengetahuan dan kemampuan menggunakan teknologi Pelleting dalam produksi pakan ternak sapi potong.

6 Terjadi peningkatan kesejahteraan anggota kelompok tani atau masyarakat sekitar dari penjualan Pellet pakan sapi potong di pasar.

\section{SARAN - SARAN}

1. Kegiatan semacam ini baru pertama kali diadakan di Desa Natai Raya Kecamatan Arut Selatan, sehingga mereka berharap ada kelanjutannya lagi.

2. Produk pakan komplit berbentuk pellet akan diaplikasikan ke sapi milik anggota perlu mendapatkan bantuan untuk peningkatan hasil produksi disarankan untuk mengajukan bantuan ke pemda setempat.

\section{UCAPAN TERIMA KASIH}

Ucapan terima kasih diberikan kepada Kemenristekdikti di Jakarta sebagai pemberi hibah pengabdian kepada masyarakat (PKM) tahun 2019, LPPM Universitas Antakusuma Pangkalan Bun yang memberikan bimbingan sehingga pengabdian ini telah berjalan dengan baik, serta Kelompok Tani Sumber Makmur di Desa Natai Raya Kecamatan Arut Selatan Kabupaten Kotawaringin Barat sebagai mitra dengan memberikan kesempatan team pengabdian untuk mengembangkan SDM dan pelatihan produksi pakan "Pellet" ternak secara sinergis dan berkesinambungan untuk memajukan produksi peternakan.

DAFTAR PUSTAKA

Laboratorium Teknologi Pakan, 2019. Hasil analisis pakan pellet. Jurusan Nutrisi dan Makanan Ternak Fakultas Peternakan Universitas Gajah Mada. Yogyakarta.

Laboratorium Teknologi Pakan. 2014. Hasil Analisa Proksimat Kacangan. Jurusan Nutrisi dan Makanan Ternak Fakultas Peternakan Universitas Gajah Mada. Yogyakarta.

Legel, 1990; Legel, S. 1990. Tropical Forage Legums and Grasses. Institute of Tropical Agriculture of the Karl-Marx-University Leipzig. Deutscher Landwirtschaftsverlag. Berlin.

LHM, 2012. STARDEC. PT. Lembah Hijau Multifarm, Solo

LHM, 2016, STARBIO. PT. Lembah Hijau Multifarm, Solo.

Mudhita, I.K., 2017. ProduktivitasIndukSapiBalidenganPakanLegumPenutup Tanah Perkebunan Kelapa Sawit Dikombinasikan dengan Pelepah dan BungkilIntiSawit. DisertasiFakultasPeternakanUniversitas GadjahMada. Yogyakarta.

Mudhita, I.K., Nafiatul Umami, Subur Priyono Sasmito Budhi, Endang Baliarti, Cuk Tri Noviandi, Kustono, I Gede Suparta Budisatriaand Jeffrie Wattimena, 2016. Effect of Bali Cattle Urine on Legume Cover Crop Puero (Pueraria Javanica) Productivity on an East Borneo Oil Palm Plantation. Pakistan Journal of Nutrition, 15(5): 406-411.

Sebayang S.Y., E.S. Sutarta, dan I.Y. Harahap. 2004. Penggunaan Mucuna bracteata pada kelapa sawit. Warta. Pusat Penelitian Kelapa Sawit Medan. 12 (2): 15 - 22. 